Acta Theriologica $36(3-4): 329$ - 348, 1991.

PL ISSN $0001-7051$

\title{
Two forms of domestic goats in Europe and Asia from the Neolithic Age to the Middle Ages
}

\author{
Alicja LASOTA-MOSKALEWSKA, Henryk KOBRYŃ and Krzysztof ŚWIEŻYŃSKI
}

\begin{abstract}
Lasota-Moskalewska A., Kobryń H. and Świeżyński K. 1991. Two forms of domestic goats in Europe and Asia from the Neolithic Age to the Middle Ages. Acta theriol. 36: 329 - 348 .

The withers height of goats (Capra hircus Linnaeus, 1758) originating from 17 countries in Europe and Asia from the time of the Neolithic Age to the Middle Ages was the subject of analyses. Two forms differing in their withers heights were separated. The small form was present in all the investigated material. Its withers height increased during the Bronze Age and the early Iron Age. The large form was not observed in the Neolithic Age. However, it was present in Greece at the turn of the Neolithic Age and Bronze Age. Then the frequency of its appearance and its territorial range increased. In none of the investigated periods was it observed in the Scandinavian countries, Estonia and Lithuania. The withers height of this large form decreased during the Bronze Age and the early Iron Age.

Institute of Archaeology, Warsaw University, Żwirki i Wigury 97/99, 02-089 Warsaw, Poland (AL-M); Department of Animal Anatomy, Warsaw Agricultural University, Nowoursynowska $166,02-766$ Warsaw, Poland (HK, KŚ)

Key words: Capra hircus, morphology, origin, evolution
\end{abstract}

\section{Introduction}

The origin of the domestic goat is the subject of much speculation and numerous hypotheses (Epstein 1971). However, it is difficult to obtain a univocal answer to the question whether it's origin is mono- or polyphyletic. These difficulties result mainly from considerable similarities in the skeleton of the domestic goat and the skeletons of a few forms of wild goats, and also from the unrestricted ability of cross-breeding.

The survey of opinions on it's origin are presented by Epstein (1971) and Mason (1981). The domestic goat belongs to the Capra Linnaeus, 1785 genus (Honacki et al. 1982). Out of many species included in that genus two are considered to be initial, namely Capra hircus Linnaeus, 1758, the aegagrus form and Capra falconeri Wagner, 1838 (Zeuner 1963, Bogolubski 1968).

The diagnostic feature of the skeleton is, most often, the shape of the horncores. However, it is not an ideal trait because this shape depends, above all, on the sex (Kobryń et al. 1991), and the mechanisms of its inheritance have not yet been fully explained. The measurements of the skeleton, so far, have not been treated as a diagnostic feature in it's taxonomy and genealogy of goat. Among other things, this could be caused by the fact that there are few 
goat bones found in excavations. Considerable dispersion of particular measurements was treated as individual variability and sometimes it was explained as the effect of sexual dimorphism.

While investigating the size of goats originating from Poland the early Middle Ages and Middle Ages, we noted that the population was not homogeneous and two forms could be distinguished, both differing in measurements of their skeletons (Świeżyński et al., in print). This observation motivated further investigations to search for the source of that particular difference. It also aimed at answering the question whether the two distinguished forms of domestic goats were present with the same frequency in different prehistoric and historic periods, or in different places of Europe and Asia. The appearance of a secular trend and geographic differentiation was also investigated.

\section{Material and methods}

The investigated material comprised of measurements of metapodial limb segments from 627 bones of domestic goats (Capra hircus Linnaeus, 1758). They were obtained from literature and from our own investigations. They originated from archeological excavations in 17 countries in Europe and South-West Asia. The bones date back to the Neolithic Age, Bronze Age, Iron Age and up to the Middle Ages (Table 1).

The length of the metapodial segments was used to calculate the withers height of goats. The following coefficients were used: 5.75 for the metacarpal bones $I I I+I V(\mathrm{McIII}+\mathrm{IV})$ and 5.34 for the metatarsal bones $I I I+I V(M t I I I+I V)($ Schramm 1967). The withers height was the product of the coefficient and the length of the bone.

In accordance to its dating all the material was divided into groups referring to particular periods: Neolithic Age (I), the turn of the Neolithic and Bronze Age (II), Bronze Age and the early Iron Age (including the Roman period) (III), the early Middle Ages and Middle Ages (IV). The countries from which the material originated were placed in alphabetic order and enumerated from 1 to 17 (Table 1). These numbers are used in Fig. 3 and 4.

The frequency distribution of withers height was examined in order to find whether they ware uni- or multimodal. Each frequency distribution was presented in the form of a cumulative distribution on the normal network. The deviation of the curve from the straight line testified the abnormality of the distribution. The compatibility of the data distribution in period II with the normal distribution was tested using the Kolmogorov test (Góralski 1976). In the case of multimodality the critical values for the withers height of goats were established, and groups were separated (called forms) and marked with the letters A (small goats) and B (large goats). The frequency of the appearance of the separated forms in each period was calculated. the differences in the frequency of their appearance were tested with the $F_{p}$ test (Góralski 1979):

$$
F_{p}=\frac{1}{n-1} \sum N_{\mathrm{i}}\left(x_{i}-\bar{x}\right)^{2}
$$

where: $n-$ number of compared groups, $\quad N_{i}-$ number of trails, $\quad x_{i}-2 \arcsin \sqrt{C_{1}}$,

$$
\bar{x}-i \sum_{=1}^{n} N_{i} x_{i} / i \sum_{=1}^{n} N_{i}, \quad C_{1}-\text { the possibility of the appearance of from B in the set } i .
$$

In each chronological group the values of $\bar{x}$ and SD of withers heitght were calculated for A and B goats. Changes, related, to age, with respect to withers height in each form (the secular trend), were tested with the $t$-Studenthitestion:

$$
\because+b_{2} ;
$$


Table 1. Origin of the material studied.

\begin{tabular}{|c|c|}
\hline Country & References \\
\hline 1 & 2 \\
\hline 1. Estonia & Calkin 1962. MIA. 107: 97. \\
\hline 2. Germany & 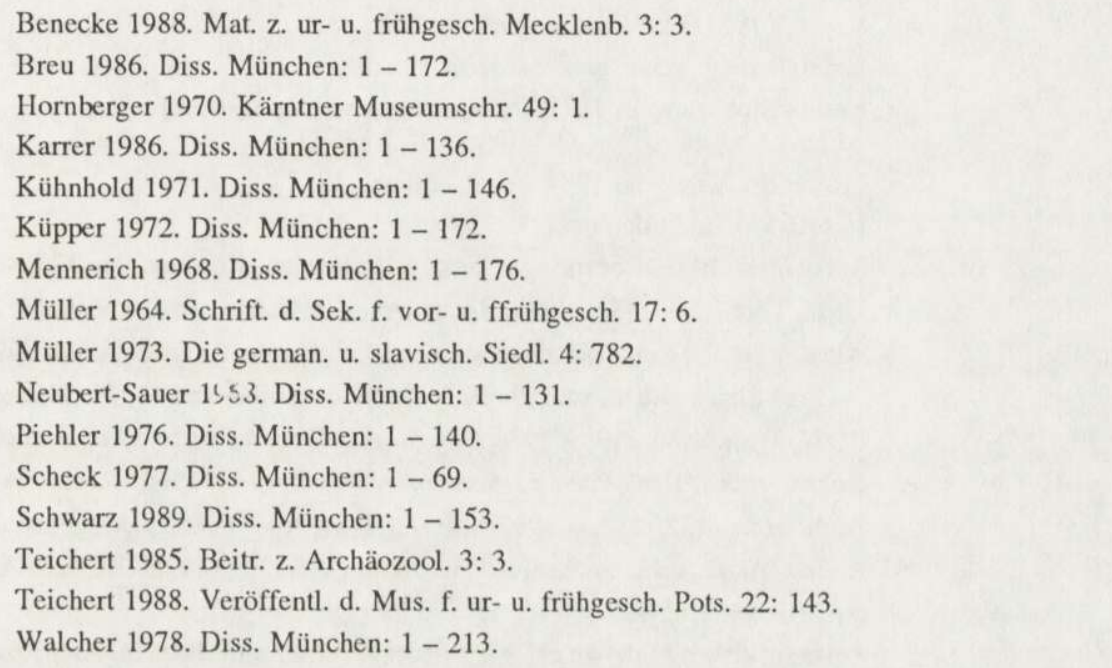 \\
\hline 3. Greece & $\begin{array}{l}\text { Amberger 1979. Diss. München: } 1-158 \text {. } \\
\text { Boessneck 1973. Die Tierknochenfunde ..... Inst. F. Paläeoanat., Domestik. u. Gesch. d. } \\
\text { Tiermed. d. Univ. München, München: } 1-32 \text {. } \\
\text { Boessneck and Driesch 1988. Knochenabfal ..... Inst. f. Paläeoanat., Domestik. u. Gesch. d. } \\
\text { Tiermed. d. Univ. München, München: } 1-46 \text {. } \\
\text { Friedl 1984. Diss. München: } 1-236 \text {. } \\
\text { Jordan 1975. Diss. München: } 1-190 \text {. }\end{array}$ \\
\hline 4. Holland & $\begin{array}{l}\text { Oudheid 1985. Bodemon. Jaar. 28: } 399 . \\
\text { Prummel 1978. Ber. Rijksdienst ondheidl. Bodenmonderz. 27: } 3 .\end{array}$ \\
\hline 5. Hungary & Bökönyi 1984. Stud. archaeol. 8: 1 . \\
\hline 6. Iran & $\begin{array}{l}\text { Krauss 1975. Diss. München: } 1-207 . \\
\text { Steber 1986. Diss. München: } 1-179 .\end{array}$ \\
\hline 7. Iraq & Boessneck and Ziegler 1987. [In: Isin-Isan Nahriyat. B. Hrouda, ed.]. \\
\hline 8. Jordan & Weiler 1981. Diss. München: 1 - 122. \\
\hline 9. Latvia & Lasota-Moskalewska, unpubl. \\
\hline 10. Lithuania & Calkin 1962. MIA. 107: 97. \\
\hline 11. Norway & Lie 1989. Riksant. Skr. norw. antiq. Bull. 4: 257. \\
\hline
\end{tabular}


Table 1. Continued

2

12. Poland

13. Spain

14. Sweden

15. Syria

16. Turkey

17. Yugoslavia
Chrzanowska 1986. Roczn. Akad. roln. Poznań, Archeozool. 172: 9.

Godynicki and Sobociński 1977. Fon. archaeol. posn. 28: 3.

Janaszek 1979. Roczn. Akad. roln. Poznań, Archeozool. 140: 19.

Krysiak 1951/52. Wiad. archeol. 18: 251.

Krysiak 1966. Wiad. archeol. 32: 376.

Lasota-Moskalewska 1977. [In: Cmentarzysko kultury amfor kulistych. J. Kowalczyk, ed.].

Lasota-Moskalewska 1984. Wiad. archeol. 49: 17.

Lasota-Moskalewska, unpubl.

Sobociński 1967. Roczn. wyż. Szk. roln. Poznań, Zootech. 36: 175. - 1969. Zesz. nauk. UMK Toruń, 33: 135. - 1973. Roczn. Akad. roln. Poznań, Zootech. 60: 63. - 1973. Roczn. Akad. roln. Poznań, Zootech. 60: 81. - 1973. Roczn. Akad. roln. Poznań, Zootech. 66: 123. - 1976. Roczn. Akad. roln. Poznań, Archeozool. 84: 35. - 1977. Mat. z ogólnopol. Symp. PWN, Warszawa: 219. - 1980. Roczn. Akad. roln. Poznań, Archeozool. 121: 79. - 1981. Roczn. Akad. roln. Poznań, Archeozool. 131: 19. - 1986. Roczn. Akad. roln. Poznań, Archeozool. 172: 137. - 1987. Roczn. Akad. roln. Poznań, Archeozool. 184. 91. - 1987. Roczn. Akad. roln. Poznań, Azcheozool. 184: 119. - 1988. Roczn. Akad. roln. Poznań, Archeozool. 198: 127.

Sobociński and Makowiecki 1987. Roczn. Akad. roln. Poznań, Archeozool. 184: 167. Schramm and Spychała-Bałęczna 1988. Roczn. Akad. roln. Poznań, Archeozool. 198: 79.

Driesch and Kokabi 1977. Archäol. u. Naturwis. 1: 129.

Undheim 1985. Hovedfag. i zool. Økol. 1: 1.

Boessneck and Peters 1988. Tierkn. u. Mollusken 3: 51.

Gautier 1984. Fouilles d'Apamée de Syrie. Miscellanea 18: 305-359.

Orthman 1989. Saarbrück. Beitr. z. Altertumsk. 52: 113.

Boessneck and Driesch 1979. Tierknochenfunde ..... Ludwig-Maximilians-Univ., München: $1-79$.

Boessneck and Driesch 1985. Knochenfunde ..... Inst. f. Paläeoanat. Domestik. u Gesch. d. Tiermed. d. Univ. München, München: 1 - 91 .

Rauh 1981. Diss. München: $1-182$.

Schäffer and Boessneck 1988. Istanb. Mitt. 38: 37.

Stahl 1989. Diss. München: $1-248$.

Bökönyi 1976. [In: Neolithic Macedonia. M. Gimbutas, ed.]. Inst. of Archaeol. Univ. California, Los Angeles: 313 - 373.

Lasota-Moskalewska, unpubl.

Sachenbacher-Palavestra 1986. Diss. München: 1-149. 
In the comparative investigations from different countries and in particular periods, a one-factor analysis of variance (ANOVA) was used. The differences between the mean values characteristic for the whole period, called the standard, were also calculated.

The similarities between the mean withers heights of goats originating from different countries were examined using the method of least differences - forming Czekanowski's diagram (Jasicki et al. 1962).

The potential for separating the metacarpal bones $I I I+I V$ belonging to males and females were examined in the correlation field, marked out by the length of the bone and the width of its shaft according to Calkin's method (1960) calculated for domestic cattle.

The point scale was constructed for four measurements: length of McIII + IV, length of MtIII + IV withers height and length of horncore according to the method previously described (Lasota-Moskalewska. 1984, Lasota-Moskalewska et al. 1987). The data concerning the length of the horncore were taken from the paper by Świeżyński et al. (in print). This material comprised part of the material used in the present experiment, namely the horncores of goats originating from Poland during the early Middle Ages and Middle Ages.

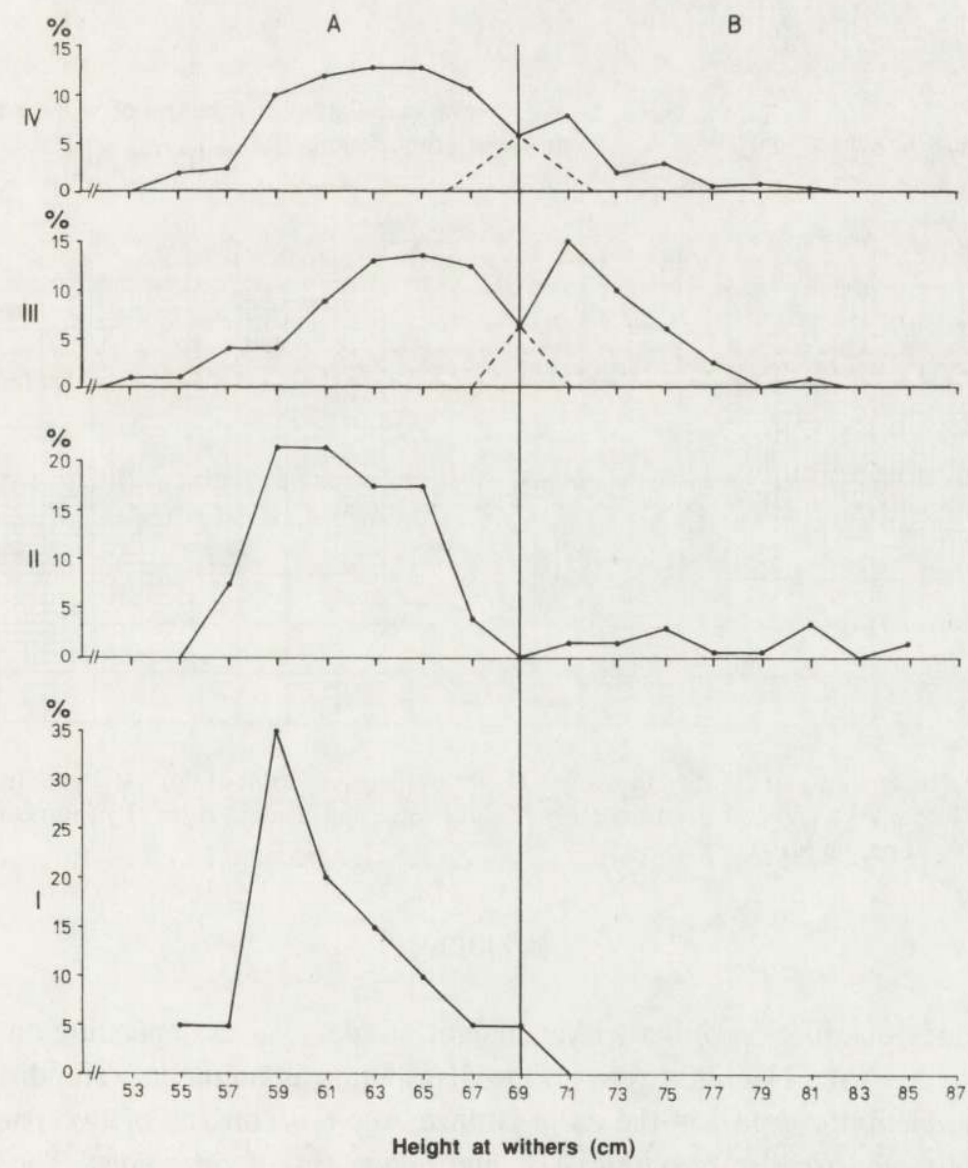

Fig. 1. The frequency distribution of withers height in domestic goats. A - small form, B - large form, I - Neolithic Age, II - the turn of the Neolithic Age and Bronze Age, III - Bronze Age and the early Iron Age, IV - early Middle Ages and Middle Ages. 


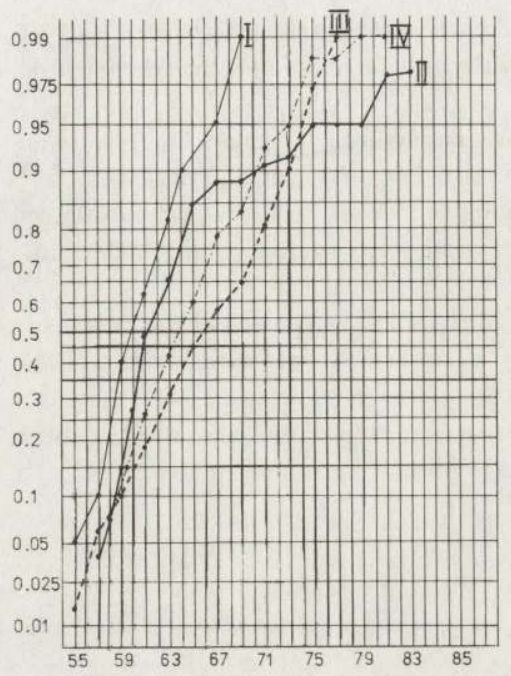

Height at withers $(\mathrm{cm})$
Fig. 2. The cumulative distribution of withers height of goats from different periods (I - IV).
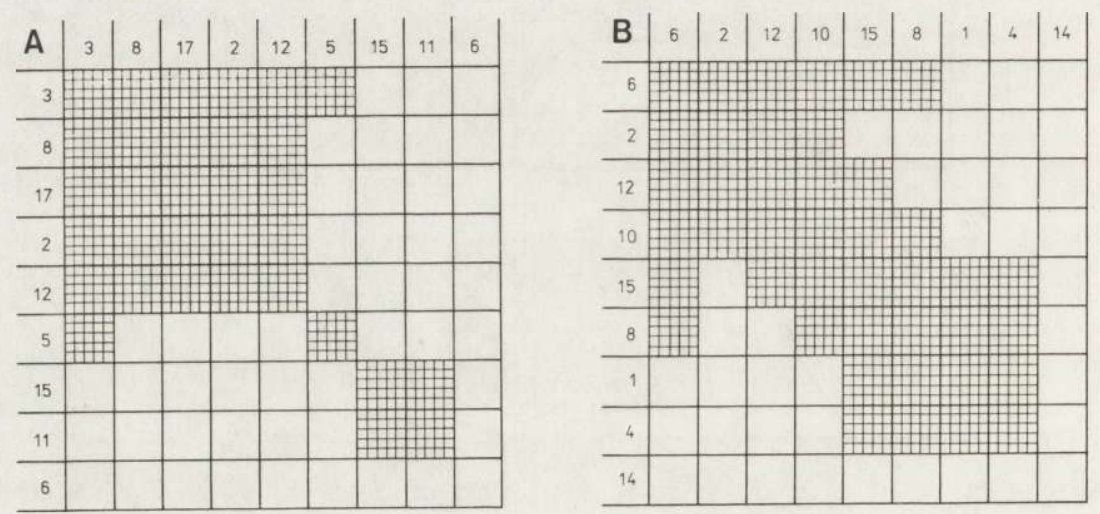

Fig. 3. Diagram of the greatest similarities in withers height of the small form of domestic goat from the Bronze Age and the early Iron Age (A) and from the early Middle Ages and Middle Ages (B) (numbers of countries agreing with their ordinal numbers in Table 1).

\section{Results}

The frequency distribution of the withers height of goats varies depending on their period of origin (Fig. 1). In the Neolithic Age (I) the distribution is unimodal. The distribution for the turn of the Neolithic Age and the early Bronze Age (II) consists of two parts. The first part is similar to that of the Neolithic Age and comprises of 58 values. The second one comprises of only 7 values and because of the small number of cases, they do not form a consistant distribution. The distribution from the Bronze Age and the early Iron Age (III) is clearly bimodal, with two distinguishable sets overlapping and forming a common trans- 
gression zone not smaller than $4 \mathrm{~cm}$. The distribution of the withers hight of goats from the early Middle Ages and Middle Ages (IV) is also bimodal. It seems that the overlapping zone of both sets is slightly bigger than the preceding distribution and not smaller than $6 \mathrm{~cm}$. The curves of the cumulative distribution show that the distribution for period I is closest to the normal, while for period II differs the most (Fig. 2). These results were calculated using the Kolmogorov test i.e. the distribution for period II differs from the normal in a statistically significant way $(p<0.01)$.

The comparison of all four frequency distributions allows the investigated material to be distinguished into two groups of goats differing in their withers height. As a limit value between the two groups the height of $69.0 \mathrm{~cm}$ was accepted. In this paper these groups will be called forms A and B. Form A comprises of goats smaller than $70 \mathrm{~cm}$ at withers and form B - goats of the height equal or bigger than $70 \mathrm{~cm}$. That fixed division was necessary for a clear classification. The limit value is quite true for goats from the turn of the Neolithic Age and the early Bronze Age. For goats living in the later periods that value is only approximate referring to a smaller frequency expressed by the bend in the frequency distribution curves.

Form A was observed in all the examined remnants irrespective of the region and period (Table 2). Form B was not observed in material originating from the Neolithic Age (I). At the turn of the Neolithic and Bronze Age (II) this form was found in two excavation sites out of three. In the Bronze Age and early Iron Age (III) form B was observed in 6 sites out of 10 , while in the early Middle ages and Middle Ages (IV) it appeared in 5 sites out of 10 .

In order to investigate the frequency of appearance of form B goats in particular chronological groups, material from certain countries was used where both forms A and B appeared together (Table 3). The frequency of form B in the four investigated periods differs significantly $\left(F_{p}=152.45>F_{p}(0.01,3,158)=4.73\right)$. The highest frequency observed in the Bronze Age and the early Iron Age (III) amounts to $39 \%$. In the earlier period (II) it is lower (21\%). In the early Middle Ages and Middle Ages (IV) it amounts to $25 \%$.

The amount of data from Germany and Poland were large enough to compare the change in frequency of appearance of form B goats in this region. From the Bronze Age and early Iron Age to the early Middle Ages and Middle Ages the frequency of form B goats in Germany decreased from $39 \%$ to $24 \%$, and in Poland from $24 \%$ to $19 \%$.

The mean withers height of form A goats for all the regions together, in the compared periods amounts to 61.2 to $63.6 \mathrm{~cm}$ (Table 4). During the Neolithic Age, and the turn of the Neolithic Age and the Bronze Age the mean values are lower and nearly identical. In the Bronze Age and early Iron Age, as well as in the early Middle Ages and Middle Ages, these values are also nearly identical but higher than the previous ones by $2 \mathrm{~cm}$. This difference is statistically significant $(t=3.494>t 0.01=2.576, v=161)$.

The mean withers height of form B goats amounts to 77.3 to 72.9 in the three compared periods. The highest value was in period II, the lowest in III and the difference between them is statistically significant $(t=4.026>t 0.01=2.660, v=61)$. In period IV the height of form $\mathrm{B}$ goats is nearly identical as in the earlier period (III).

Some differences are observed in the mean arithmetic values of withers height in the case of goats from different regions, even during the same chronological period and the same form of goats (Table 2). However, the ANOVA carried out for form A showed that the mean values 


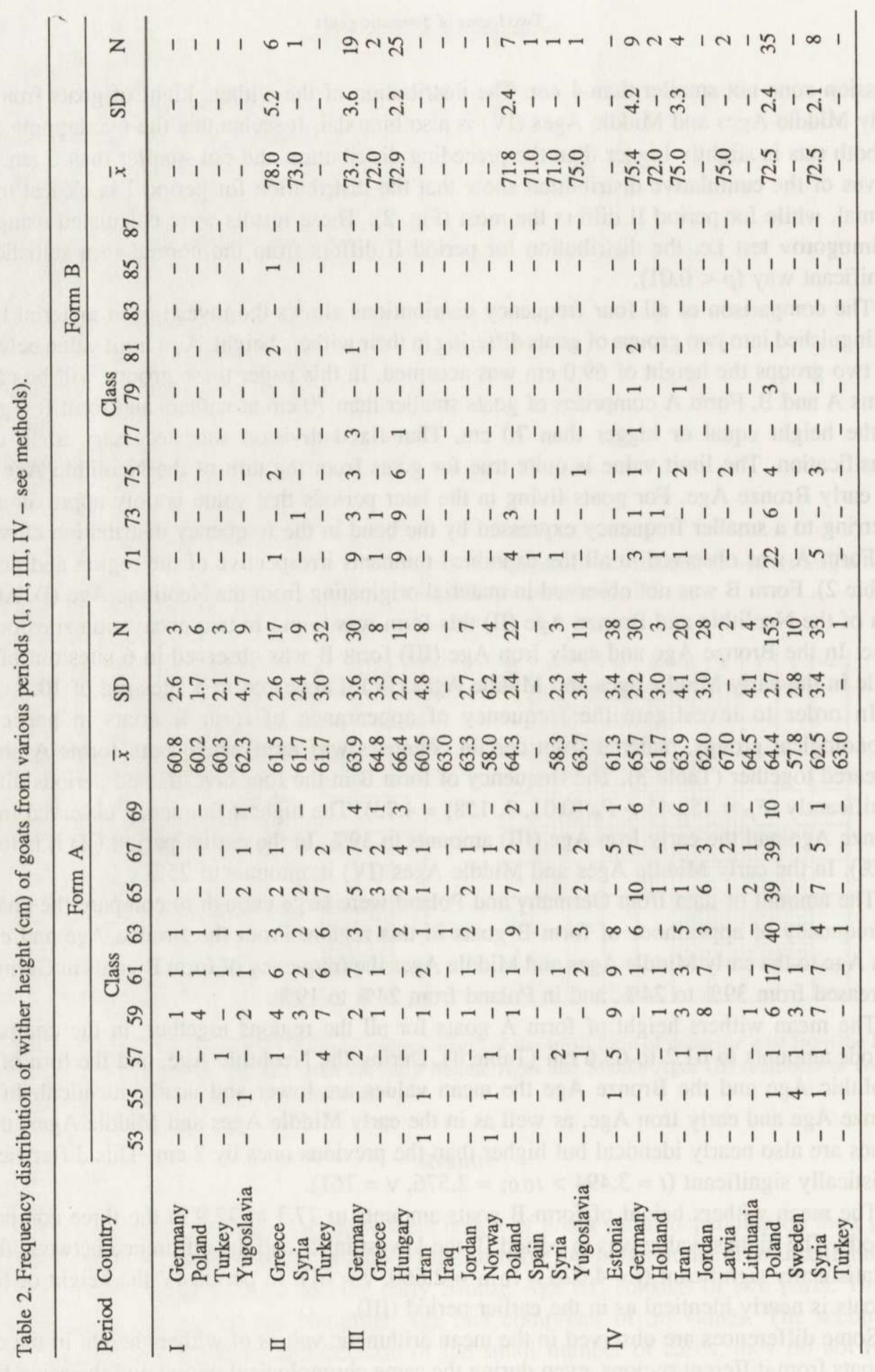


Table 3. Frequency of A and B goat forms in various periods.

\begin{tabular}{|c|c|c|c|c|c|}
\hline \multirow{2}{*}{ Form } & \multicolumn{4}{|c|}{ Period } & \multirow{2}{*}{ Total } \\
\hline & I & II & III & IV & \\
\hline A & 21 & 26 & 85 & 241 & 373 \\
\hline B & - & 7 & 55 & 60 & 122 \\
\hline Total & 21 & 33 & 140 & 301 & 495 \\
\hline
\end{tabular}

Table 4 . Wither height $(\mathrm{cm})$ of goats in various periods.

\begin{tabular}{lccccccc}
\hline & \multicolumn{3}{c}{ Form A } & & \multicolumn{3}{c}{ Form B } \\
\cline { 2 - 5 } \cline { 6 - 8 } \cline { 6 - 8 } & $\bar{x}$ & $\mathrm{SD}$ & $\mathrm{N}$ & & $\bar{x}$ & $\mathrm{SD}$ & $\mathrm{N}$ \\
\hline I & 61.2 & 3.3 & 21 & & - & - & - \\
II & 61.6 & 2.8 & 58 & & 77.3 & 5.1 & 7 \\
III & $63.6^{*}$ & 3.8 & 105 & & $72.9^{*}$ & 2.2 & 56 \\
IV & 63.5 & 3.4 & 321 & & 73.2 & 2.9 & 60 \\
\hline
\end{tabular}

* Difference between period II and III are significant $(p=0.01)$.

of the height of goats from four countries during the Neolithic Age (I) make up a homogenous set $\left(F=0.0018<F_{0.05}=3.20, v_{1}=3, v_{2}=17\right)$. Also nine arithmetic means of the heights of goats from all the investigated countries during the Bronze Age and the early Iron Age (III) do not differ in a significant way $\left(F=0.668<F_{0.05}=2.03, v_{1}=8, v_{2}=95\right)$. A similar result was obtained for nine mean heights of goats from the early Middle Ages and Middle Ages (IV: $F=0.621<F_{0.05}=1.97, v_{1}=8, v_{2}=310$ ). Such an analysis was not done for form A goats because they are nearly identical (Table 2).

The height of form A goats from particular countries with a common mean called 'the standard' were compared in given periods. It was observed that in the Bronze Age and the early Iron Age (III) smaller than the standard were goats from Iran, Syria and Norway and significantly bigger from Hungary. In the early Middle Ages and Middle Ages (IV), goats from Sweden and Estonia were smaller than the standard and the goats from Germany - bigger than the standard (Table 5). In the two earliest periods such differences were not analysed because of very slight differences in arithmetic means.

In two later periods (III and IV) in which the observed differences between the arithmetic means, originating from different regions, were bigger by $2 \mathrm{~cm}$, the method of the least differences was applied. Results from diagram (Fig. 3A) show that in the Bronze Age and early Iron Age the most similar form A goats are from Greece, Jordan, Yugoslavia, Germany and Poland. Goats from Norway, Syria and Iran show the greatest differences when compared with goats from all the other countries. They are also smaller than the others. Goats from Hungary are similar only to the goats from Greece. 
Table 5. Differences (in $\mathrm{cm}$ ) between means of wither height of A and B goat forms, and standard, representing the mean characteristic for the given period.

\begin{tabular}{|c|c|c|c|c|}
\hline \multirow{2}{*}{ Country } & \multicolumn{2}{|c|}{ Form A } & \multicolumn{2}{|c|}{ Form B } \\
\hline & $\begin{array}{c}\text { Period III } \\
(\text { standard }=63.6 \mathrm{~cm})\end{array}$ & $\begin{array}{c}\text { Period IV } \\
(\text { standard }=63.5 \mathrm{~cm})\end{array}$ & $\begin{array}{c}\text { Period III } \\
(\text { standard }=72.9 \mathrm{~cm})\end{array}$ & $\begin{array}{c}\text { Period IV } \\
(\text { standard }=73.2 \mathrm{~cm})\end{array}$ \\
\hline Estonia & - & -2.2 & - & - \\
\hline Germany & +0.3 & +2.2 & +0.8 & +2.2 \\
\hline Greece & +1.2 & - & - & - \\
\hline Holland & - & -1.8 & - & - \\
\hline Hungary & +2.8 & - & 0.0 & - \\
\hline Iran & -3.1 & +0.4 & - & +1.8 \\
\hline Jordan & -0.3 & -1.5 & - & - \\
\hline Lithuania & - & +1.0 & - & - \\
\hline Norway & -5.6 & - & - & - \\
\hline Poland & +0.7 & +0.9 & -1.1 & -0.7 \\
\hline Sweden & - & -5.7 & - & - \\
\hline Syria & -5.3 & -1.0 & - & -0.7 \\
\hline Yugoslavia & +0.1 & - & - & - \\
\hline
\end{tabular}

In the early Middle Ages and Middle Ages two groups of from A goats were separated in respect to their height at withers (Fig. 3B). One group, the larger, comprised of goats from Iran, Germany, Poland and Lithuania. The other group, the smaller, were comprised from Syria, Jordan, Estonia and Holland. However, both groups show some similarities between pairs, for example, goats from Syria and Iran, or Syria, Poland and Lithuania. The goats from Sweden differ from all others and are smaller.

The ANOVA of the withers height was carried out only for form B goats from the two later periods (III and IV). In the material from the Neolithic Age there were no form B goats and at the turn of the Neolithic Age and the Bronze Age they were only present from Greece and one animal from Syria.

It has been shown that in period III the differences between the withers height of goats from Poland, Germany and Hungary are not significant $\left(F=0.114<F_{0.05}=3.18, v_{1}=2\right.$, $v_{2}=48$ ). In the case of other countries the number of form B goats was too small. No variation has been shown between the height of goats from Syria, Iran, Germany and Poland in period IV $\left(F=0.331<F_{0.05}=2.78, v_{1}=3, v_{2}=52\right)$.

The differences between the mean withers height of form B goats and the mean characteristic for the given period (standard) in the Bronze Age and the early Iron Age (III) were very small. In the early Middle Ages and Middle Ages (IV) the mean heights of goats from Germany and Iran were a little larger than the standard (Table 5). In view of a high similarity in all the mean values the method of least differences could not be used. It should be noted that in the early Middle Ages and Middle Ages identical withers heights were present in form B goats from Syria and Poland and a little greater in goats from Iran and Germany. 


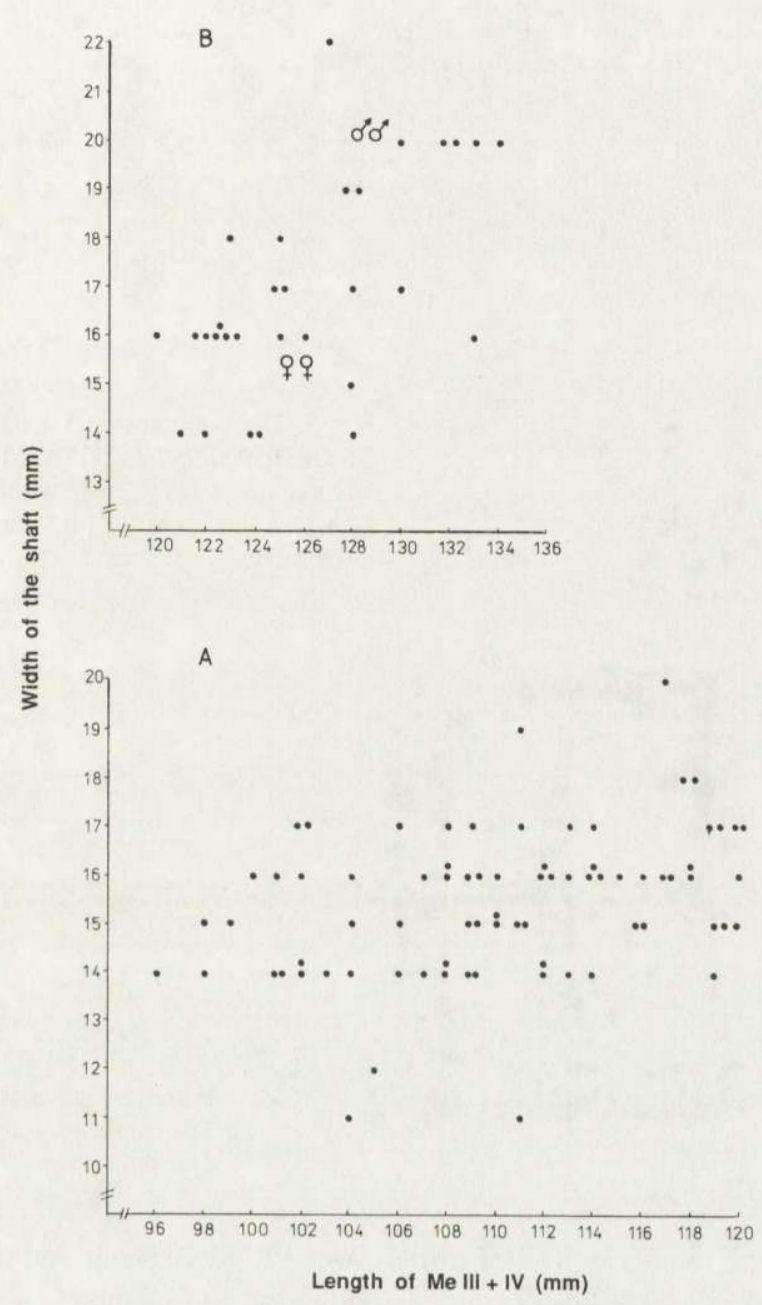

Fig. 4. Correlation of length and width of the shaft of os metacarpale III+IV from Poland. A - small form, B - large form.

In order to investigate the possible effect of sexual dimorphism on the obtained results, a trial was undertaken at separating McIII+IV of males and females on the correlation field made up by the length and shaft width of that bone (Fig. 4). In form A goats no correlation was observed. Also, it was not possible to separate males and females. In form B goats a tendency for a linear dependence between the investigated features was noted.

In accordance to the accepted interpretation of similar distribution (Calkin 1960) it can be accepted that 8 bones, represented by points located in the furthest upper right hand corner, belong to males. These bones were characterized by a length from 127 to $134 \mathrm{~mm}$ and the shaft width from 19 to $22 \mathrm{~mm}$. They comprised $26.7 \%$ of all bones examined in that correlation 
Fig. 5. The point scale $(0-100)$ of the length of the os metacarpale $I I I+I V$ (a), the length of the os metatarsale $I I I+I V$ (b), withers height (c) and the length of the horncore (d). Clear fields - small form, b d lined field - large form.

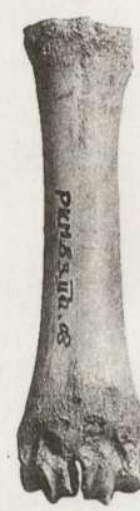

B

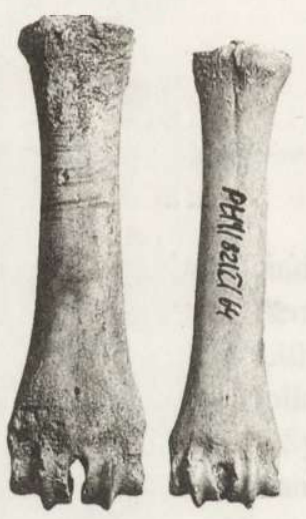

B

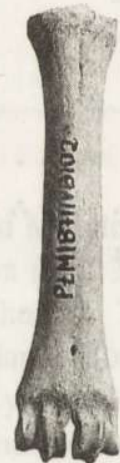

A

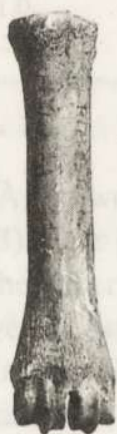

A

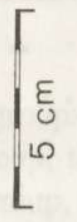

Fig. 6. Os metacarpale $I I I+I V$ of domestic goats belonging to large form (B) and small form (A). Photo by M. Dąski.

field. The length of the remaining bones varied from 120 to $133 \mathrm{~mm}$ and the shaft width from 14 to $18 \mathrm{~mm}$. These bones can be accepted as belonging to females.

In order to make the separation of bones of form A and B goats, as well as their height, easier, a graph based on the point method was drawn (Fig. 5). The critical place on a point scale is the segment between 40 and 60 points. The values of the features between points 40 and 60 represent both forms. The differences in size and proportions of the McIII+IV, between these two forms of goats, are presented in Fig. 6.

\section{Discussion}

In the investigated material two forms of goats differing in withers height were separated. These forms appeared in different regions of Europe and Asia, and at different times. All the investigated distributions of withers height values showed a near identical critical point between each form (about $70 \mathrm{~cm}$ ). 


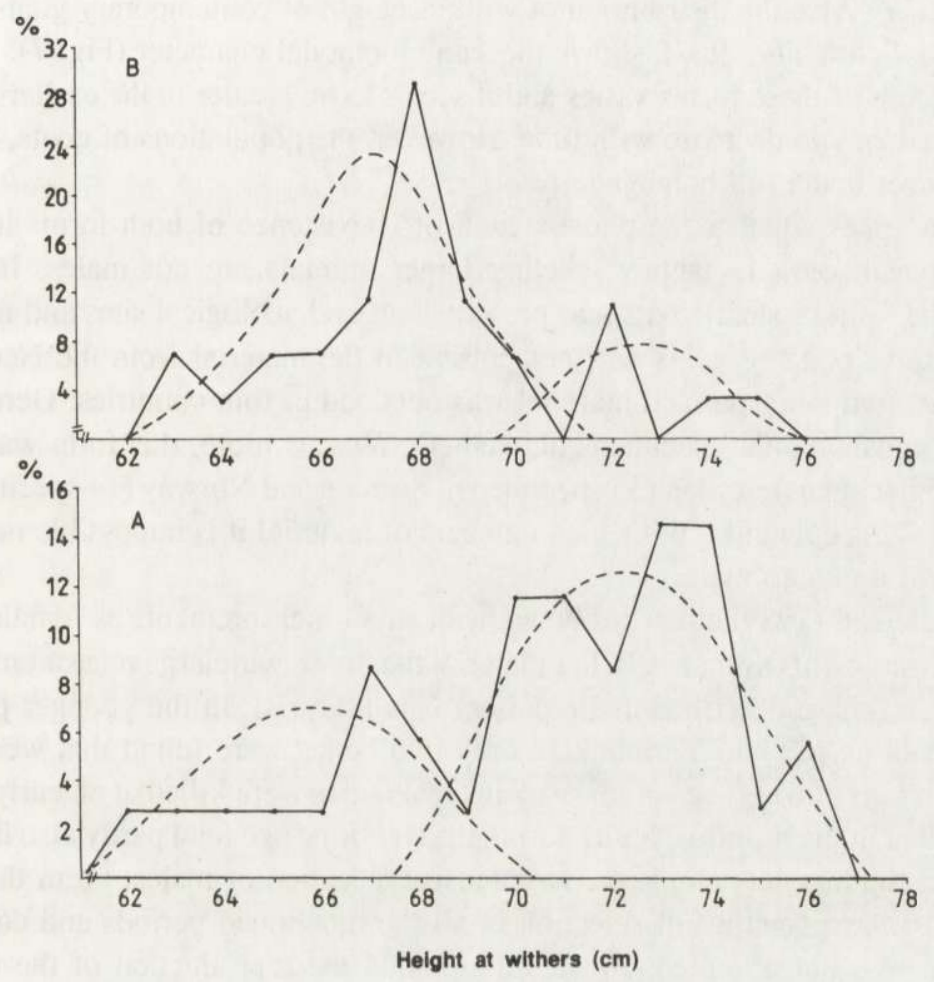

Fig. 7. The frequency distributions of withers height of the domestic goat: A - from the town Tać-Gorsium (data by Bökönyi 1984), B - contemporary female goats (data by Schramm 1967). Continuous line - empirical data, dashed line - equalized curve.

The differentiation of goats was not surprising because a similar result was obtained earlier while investigating osseous material originating from Poland during the early Middle Ages and Middle Ages (Świeżyński et al., in print). The confirmation of the phenomenon with more numerous material, a more extensive region and the period of about 6000 years testifies to its universal and greater biological significance. The variability of the size of goat skeleton was also noted by Köhler-Rollefson (1989) while investigating the early Neolithic excavation site in Jordan. The author did not possess the values of the length measurements of the long bones. Bimodal distributions were obtained for the three features of width and the length of talus. This phenomenon was interpreted as the effect of sexual dimorphism, an opinion discussed below.

The analysis of the distribution of withers height of goats from Tać-Gorsium - a Roman province in the region of Hungary investigated by Bökönyi (1984) also shows the possibility of separating two groups of goats (Fig. 7). Although he says that "these values reflect a goat stock which is quite homogeneous in character" but the curve drawn by us possesses a clear bend at the level of the value accepted by us as critical between the two forms. Similar groups can be separated in the archaeozoological material from the region of Poland investigated by 
Schramm (1967a). Also the distribution of withers height of contemporary goats from Poland, investigated by Schramm (1967), shows the same biomodal character (Fig. 7).

The separation of these forms varies and it seems to be greater in the earlier periods, when it showed a tendency to decrease with time. However, the populations of goats, which include both forms, never reach full homogeneity.

A question arises whether the phenomenon of coexistence of both forms is the effect of sexual dimorphism or not, namely whether larger animals are not males. In the material investigated the form of small goats was present at all archaeological sites and in every period of time. The form of large goats was not present in the material from the Neolithic Age in spite of the fact that the examined material was obtained in four countries: Germany, Poland, Turkey and Yugoslavia (21 specimens altogether). What is more, this form was never found in Turkey (33 specimens), Jordan (35 specimens), Sweden and Norway (14 specimens). Estonia and Lithuania (42 specimens). With such numbers of material it is impossible not to find even a single bone of a mature male.

Köhler-Rollefson (1989) classifies bones with small measurements as females while those with large measurements as males. In her material the bones with large measurements appeared only in the older phase described as Prepottery Neolithic (B). In the younger phase dated as Prepottery Neolithic $(C)$ and Yarmoukian only two bones were found that were bigger than the main group (out of 62). The author explains that males were killed at an early age. It seems very unlikely that in the primitive herds during the Neolithic age (and partly also in the aceramic Neolithic Age) the breeders employed an intensive selection of males. From the investigated material it must have been a full selection in all the mentioned periods and countries where the large form was not observed. In such a situation the reproduction of the domestic goat must have met great difficulties.

Most often the proportion of small goats to large ones, in the investigated material, is $2: 1$. In the town of Tać-Gorsium (Hungary) this ratio was reversed to $1: 2$. It is hard to believe that in that town all young females were killed and only young males were left for further breeding.

While investigating the differentiation of goats in medieval Poland (Świeżyński et al., in print), the McIII+IV and MtIII+IV were divided into those belonging to males and females using the width and length coefficients in accordance to the data obtained by Schramm (1967) on present-day goats. The distribution of withers height was investigated separately for each sex. These distributions were also biomodal and the numbers of small and large bones formed approximately the ratio $2: 1$. Within the same form males and females only slightly differed in the length of the bones, but clearly differed in the width measurements. These differences could be related to the considerably greater body weight of males which, according to Köhler-Rollefson (1989), in wild forms, exceeds the body weight of females by about $14 \mathrm{~kg}$. The fact of greater withers height in males is often stressed. This difference can be the result of differences in the length of limb bones other than the metapodia. Such a possibility was pointed out by Schramm (1967) who reported that withers often varied in cases of identical lengths in McIII+IV.

The attempt at separating the bones of McIII+IV of males and females, produced different results in both goat forms. In the case of the McIII+IV belonging to the small form no 
correlation was observed between the length of the bone and the width of its shaft. In larger form, more or less, $1 / 4$ of bones were separated from all the others, and because of their localization in the correlation field they could be accepted as belonging to males. It is possible that the form reached such a level of domestication that the sex differences in the measurements of the skeleton disappeared. A similar phenomenon is observed in domestic cattle. Bos taurus brachyceros which show considerably smaller sexual dimorphism than the more primitive form - Bos taurus primigenius. The measurements of McIII+IV of the first form do not separate in the correlation field (Lasota-Moskalewska 1980). The large form goats which lived in Poland in the Middle Ages also showed greater sexual dimorphism than small form goats (Świeżyński et al., in print).

The hypothesis that the two forms of goats described in this paper do not result from sexual dimorphism is supported by a study by Schramm (1967) on 28 present-day female goats. In this group we also observed the existance of two forms (Fig. 7).

Summing up, it can be said that the two forms of goats distinguished differ in the length of McIII+IV and MtIII+IV which is reflected in their withers height. Possibly these forms also differ in the length of their horncores. Results from Świeżyński $e t$ al. (in print) indicate that this feature is not correlated with sex and differentiates into two groups. Archaeozoological material does not allow the possibility of matching horncores with the metacarpals and metatarsals. However, it can be expected from the numerical ratio in the investigated material that in nature the following relationship can be observed: small form - short horncores, large form - long horncores.

In our material the small form was present more frequently than the large form. The exception is the material from Tać-Gorsium (Bökönyi 1984). However, the ratios between these two forms were not constant for the whole of the investigated period covering 6000 years. The large form was not observed in the Neolithic Age. Of course, the scantiness of material from that age does not allow a full generalization. Although the investigated bones originated from only four countries they were still located in different climatic and cultural zones (Table 2). Despite these differences, the large goat form was not found in these countries. In the material from 'Ain Ghazal, Köhler-Rollefson (1989) noted the presence of the large form goats in Jordan in the Prepottery Neolithic Age, but in the earlier phase of the Neolithic Age they were not yet present. In view of our results, it is possible to accept that these goats represented the large form. It would be the earliest appearance of that form which died out in the Neolithic Age. In the area of Jordan these goats did not appear in the Bronze Age, early Iron Age or in the Middle Ages.

Similarly in Turkey and Iran the large form was not present in the material from the Neolithic Age, Bronze Age and the early Iron Age. Large goats appeared in Syria and Iran only in the early Middle Ages and in the Middle Ages.

There is also another possible interpretation suggested by the author, namely that large bones in the material from 'Ain Ghazal originated from wild goats (Köhler-Rollefson 1989). It should be stressed that the material could not be directly compared with ours because they delt with other metric features, and did not include the measurements of the metapodia.

In our material, the large goats appeared for the first time at the turn of the Neolithic Age and Bronze Age in Greece at the Mogula Pevkakia excavation site connected with Dimini 
Cultur and Rachmani Cultur (Jordan 1975). In the later period, namely in the Bronze Age and the early Iron Age, a considerable increase in the number of large form goats were observed. Its range included the basin of the Mediterranean Sea and Central Europe where its frequency was quite high, especially in Hungary and Germany. In the early Middle Ages and Middle Ages the number of large form goats decreased, although its territorial expansion was still large. It should be stressed that there are regions where the large form never appeared (Scandinavian countries and countries located on the Eastern part of the Baltic Sea). Only in Latvia were two bones of that form found. However, it was specific material because it originated from Riga (A. Lasota-Moskalewska, unpublished). In the Middle Ages that town belonged to the Hanseatic towns which had a well developed trade with Central Europe. Large goats were undoubtedly imported from the West (German colonization).

The hitherto existing theories on the origin of the domestic goat do not enable us to reconstruct the genealogy of both separated forms. It is accepted that the unquestionable ancestor, although not the only one, of the domestic goat was Capra aegagrus Erxleben, 1777, which Honacki et al. (1982) includes among C. hircus, while Corbet (1978), describing only the wild forms, separates as another species. It lived in the region of South-West Asia and also on the Greek Islands. In Asia its domestication dates back to the year 7-8 thousand BC (Mason 1981, Helmer 1989, Köhler-Rollefson 1989).

One can assume that the result of that domestication is the separated small form, because it is most numerous and widely spread. Also it shows signs of a long history as a domestic animal, such as reduced sexual dimorphism of the skeleton (Świeżyński et al., in print) and decreased withers height. This goat reaches $70 \mathrm{~cm}$ in withers height while the height of C. aegagrus may amount to $95 \mathrm{~cm}$ (Epstein 1971).

The separated large form still shows a strongly marked sexual dimorphism of metapodial skeleton and withers height amounting to $85 \mathrm{~cm}$. These features suggest that the domestication of this form occured later than in the small form. Theoretically it could have been a second act of domestication of the same wild form, namely C. aegagrus. However, in such a case, crossbreeding with the goats domesticated earlier would have led to the unification if in the population of the earlier domesticated goats no change in gene frequency took place (e.g. as the effect of selection). Still the unification of the population did not happen because even in the Middle Ages there were two separated forms although an overlap occured between them. The large form probably originates from a different form of wild goat. This goat must have had longer metapodia than $C$. aegagrus and probably had greater withers height. Possibly it also had longer horncores. It is difficult to determine the shape of these horncores. It can be said that they were not screwshaped, as this particular shape was not observed (Kobryn et al. 1991). They could have been scimitarshaped in both sexes or scimitar in females and twisted in males.

We cannot point out any form of wild goat that could fulfil the above description. Possibly comparative studies of skeleton measurements, especially metapodias and horncore length of different forms of wild goats would arouse some suggestions.

The fact that in our material the large form of goat first appeared in Greece does not settle the question of where the second act of domestication took place. At the turn of the Neolithic and the Bronze Age, Mogula Pevkakia, the place from which the material originated, was a 
port with a lively trade serving the town of Dimini. The possible import of the large form of goat would have occured, so to improve the breeding of animals and the exterier of small goats locally bred. We do not know what the source of that import was. It was not Turkey because despite quite numerous material the large form was not found there. However, import from other parts of South-West Asia or even Africa should not be excluded.

The time of domestication of the large form cannot be defined. However, bearing in mind our material the second act of domestication, or possibly crossbreeding of domestic goats with a second form of the wild ancestor, could not have taken place later than the Neolithic Age.

It should also be analysed what, in view of our results, is the position of $C$. prisca Adametz et Niezabitowski, 1914. The questioning by Thenius et al. (1962) of the hypothesis on it's appearance in the wild state in Pleistocene Europe does not dismiss the fact that the forms answering to the primary description sometimes appear in the excavated remains (Ducos 1968, Bökönyi 1974).

In the material from medieval Poland, skull and horncore fragments were found differing from those which were the most common at that time (Fig. 8). This variation consisted of considerably thick skull bones, their large measurements, lack of horncore pneumatization and larger length. As that length exceeded $200 \mathrm{~mm}$ we can assume that those skulls belonged to goats morphologically similar to form B goats. With an infrequent appearance of this particular type of skull and horncore it is proved that they cannot be connected with the small form A. These skulls show great similarity to the descriptions and pictures of $C$. prisca. The horncores

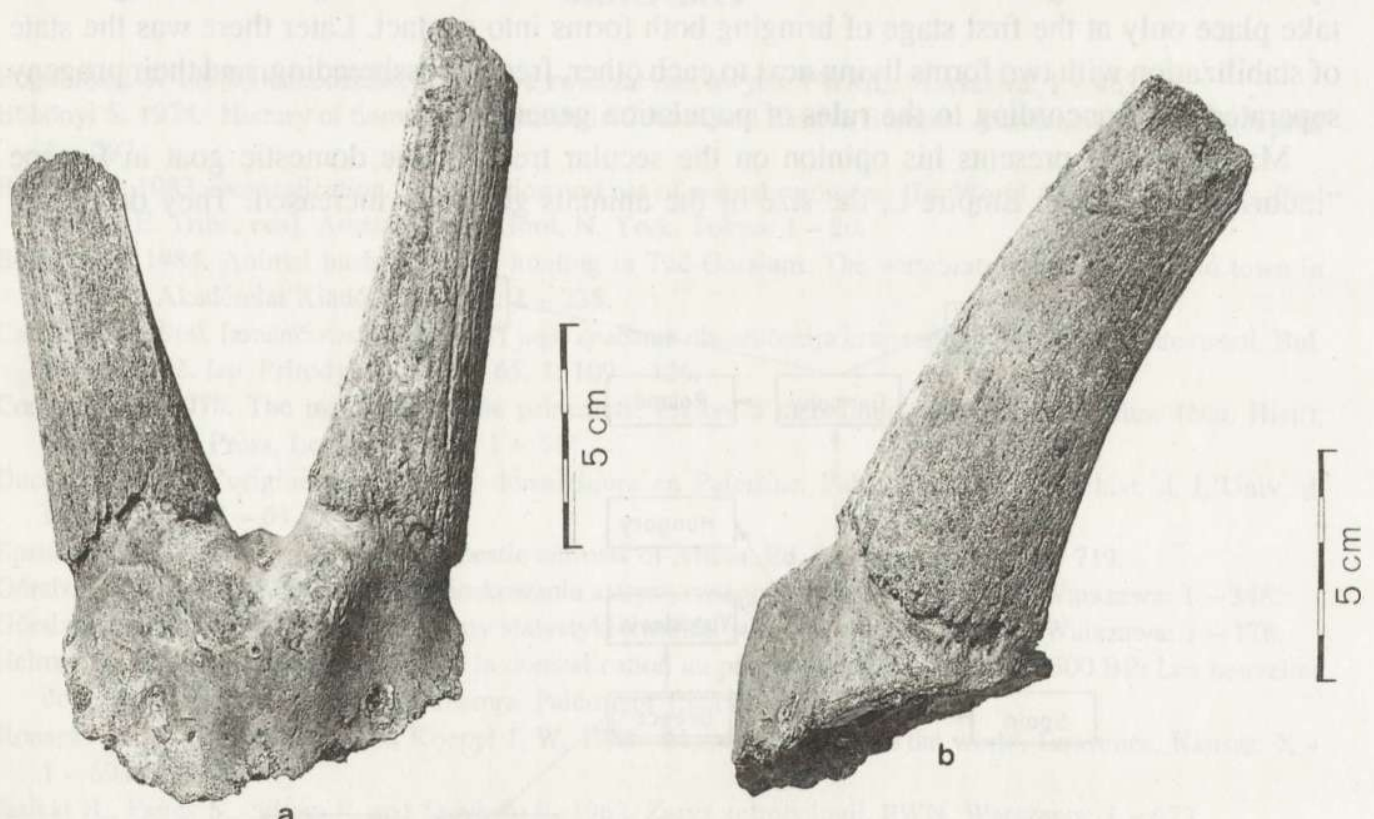

Fig. 8. Skull fragment from a domestic goat from the medieval town of Plock (Poland), resembling Capra prisca (a - norma frontalis, b - norma lateralis). Photo by M. Dąbski. 
at their base are very close to each other, growing back-wards and sideways. In males they are slightly twisted and homonomic. The outside surface of the horncores is covered with decp grooves and openings connected with the vascular system.

In view of our results $C$. prisca could be a domestic goat morphologically similar to the large form B. It was propably domesticated later than the small form A - descending from C. aegagrus. The skulls with the most primitive structure, treated sometimes as wild goas, may belong to the extreme form of large goats.

If we treat the Balkan Peninsula as the first place where the large form of domestic gcat appeared in Europe, then its expansion was logically arranged (Fig. 9). In the Bronze Age ard the early Iron Age that form was present in the Mediterranean Sea basin which was influenced by Aegean culture. The it spread to the areas conquered by the Roman Empire - Tać-Gorsium is the best example of this. Similarly in Germany the amount of large goats was high. in Poland, which was only temporarily under Roman influence, the share of these goats was much lower. The large form never reached the Scandinavian Peninsula and Baltic countries. It alıo never reached Jordan and Turkey although in the Middle Ages it appeared in Syria and Ira.

Both forms of goats, showed a secular trend in withers height during the period of about 6000 years. Small goats increased in withers height during the Bronze Age and the early Iron Age. In the Middle Ages their height did not change any more. The large form decreased n height in the Bronze Age and the early Iron Age, and in the Middle Ages it did not chang. Thus the changes in size occured in the same period, however, the tendencies in the seculir trend were reversed in both forms. Such a tendency of this secular trend can only be explained by the crossbreeding of both forms and their increasing unification. A significant change coud take place only at the first stage of bringing both forms into contact. Later there was the stae of stabilization with two forms living next to each other, freely crossbreeding, and their progery separated itself according to the rules of population genetics.

Mason (1981) presents his opinion on the secular trend in the domestic goat in Eurofe “...during the Roman Empire ... the size of the animals generally increased. They decreased

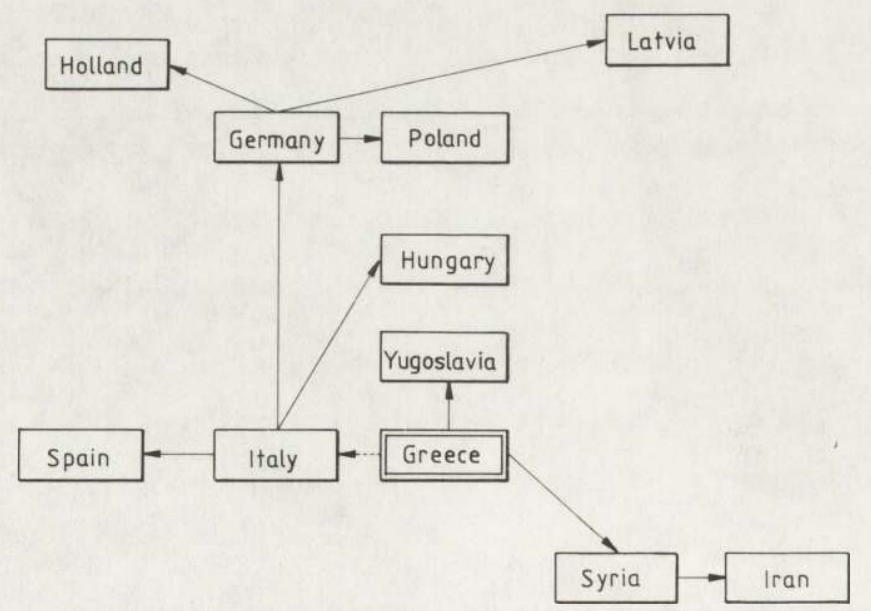

Fig. 9. The hypothetical directions of spreading of the large form of goats. 
again up to the fourteenth century $\mathrm{AD}$ after which they again increased in size". In view of our research the first increase in withers height in European goats was connected with a rapid spread of the representatives of the large form. This agrees with observation by Bökönyi (1983) who says: "More large goats occured in the Roman Imperial Period, probably from some Italian improved breed".

Variability in withers height was observed in each form depending on their region of origin. This variation was not large enough as to question the homogeneity of goats within each form. The small form from the regions of Hungary, Germany, Poland, Greece and Yugoslavia (Macedonia) were higher than the goats from the remaining countries. This phenomenon may have resulted from the set of ecologic and climatic conditions. However, it seems that the main reason was the effect of heterosis because in these regions both forms had easy contact.

The smallest goats were observed in Norway, Sweden and Estonia. The large form never appeared in those regions. Thus inbreeding of the small form and adverse environmetal conditions culd have affected the size of goats. It is difficult to consider the geographic variation of large goats because of lack of material.

The results presented do not solve the still controversial problem of the origin of domestic goats. However, they justify the necessity to consider the hypothesis on the second stage of the domestication of goats, possibly from another wild form. The results comprise the first proof for the dual origin of the domestic goat based on the analysis of quantitative features.

Acknowledgements: Many thanks are due to Mr Ewen McNeish for linguistic correction of the text.

\section{References}

Bogolubski S. 1968. Pochodzenie i ewolucja zwierzat domowych. PWRiL, Warszawa: $1-462$.

Bökönyi S. 1974. History of domestic mammals in Central and Eastern Europe. Akadémiai Kiadó, Budapest: $1-597$.

Bökönyi S. 1983. Domestication, conservation and use of animal resources. [In: World Animal Science. L. Peel and D. E. Tribe, eds]. Amsterdam, Oxford, N. York, Tokyo: 1-20.

Bökönyi S. 1984. Animal husbandry and hunting in Tać-Gorsium. The vertebrate fauna of a roman town in Panonia. Akadémiai Kiadó, Budapest: 1 - 238.

Calkin V. J. 1960. Izmenčivost metapodii i jego značenie dla izučenija krupnogo rogatogo skota drevnosti. Bul. Mosk. Obšč. Isp. Prirody, Otd. Biol. 65, 1: $109-126$.

Corbet G. B. 1978. The mammals of the palaearctic region: a taxonomic review. British Mus. (Nat. Hist.). Cornel Univ. Press, London, Ithaca: $1-314$.

Ducos P. 1068. L'origine des animaux domestiques en Palestine. Publ. d. L'Inst. d. Préhist. d. L’Univ. d. Bordeaux 6: $57-61$.

Epstein H. 1971. The origin of the domestic animals of Africa. Ed. Leipzig, Leipzig: $1-719$.

Góralski A. 1976. Metody opisu i wnioskowania statystycznego w psychologii. PWN, Warszawa: $1-348$.

Góralski A. 1979. Algorytmy i programy statystyki kwalitatywnej. Wyd. nauk.-techn., Warszawa: 1 - 178.

Helmer D. 1989. Le déveleoppment de la domestication au proche - orient de 9500 a 7500 BP: Les nouvelles données D’El Kowm et de Ras Shamra. Paléorient 15: 111 - 121.

Honacki J. H., Kinman K. E. and Koeppl J. W. 1982. Mammal species of the world. Lawrence, Kansas: X + $1-694$.

Jasicki B., Panek S., Sikora P. and Stoyhwo E. 1962. Zarys antropologii. PWN, Warszawa: 1 - 673.

Jordan B. 1975. Tierknochenfunde aus der Magula Pevkakia in Thessalien. Diss. Inst. f. Palaeoanatomie, Domestikationsforsch. u. Geschichte d. Tiermed. d. Univ. München. München. 
Kobryń H., Świeżyński K. and Lasota-Moskalewska A. 1991. Scimitar and twisted horncores in domestic goats from the Middle Ages. Acta theriol. 36: 163 - 170.

Köhler-Rollefson I. 1989. Changes in goat exploitation at 'Ain Ghazal between the early and late Neolithic: a metrical analysis. Paleorient 15: $141-146$.

Lasota-Moskalewska A. 1980. Morphotic changes of domestic cattle skeleton from the neolithic age to the beginning of the iron age. Wiad. archeol. 45: 119-164.

Lasota-Moskalewska A. 1984. The skeleton of a prehistoric cow with characteristic of both Primigenious and Brachycerous cattle. Ossa 9/11: $53-72$.

Lasota-Moskalewska A., Kobryń H. and Świeżyński K. 1987. Changes in the size of the domestic and wild pig in the territory of Poland from the Neolithic to the Middle Ages. Acta theriol. 32: $51-81$.

Mason I. L. 1981. Wild goat and their domestication. [In: Goat production. C. Gall, ed.]. London, N. York, San Francisco, Sydney: $36-55$.

Schramm Z. 1967. Kości długie a wysokość w kłębie u kozy. Roczn. wyż. Szk. roln. Poznań 36: 89 - 105.

Schramm Z. 1967a. Szczątki kostne wczesnośredniowiecznej owcy i kozy z wykopalisk północno-zachodniej Polski. Roczn. wyż. Szk. roln. Poznań 36: 135 - 174.

Świeżyński K., Kobryń H. and Lasota-Moskalewska A. 1991. The size differentiation of the domestic goat Capra hircus Linnaeus, 1758 at early mediaeval and mediaeval periods in Poland. Anim. Sc. Papers and Reports (in print).

Thenius E., Hofer F. and Presinger A. 1962. Capra "prisca" Sickenberg und ihre Bedeutung für die Abstammung der Hausziegen. Z. Tierzücht. u. Züchtungsbiol. 76: $321-325$.

Zeuner F. E. 1963. A history of domesticated animals. Hutchinson, London: $1-500$.

Received 25 April 1991, accepted 23 November 1991. 